Research Article

\title{
Evaluation of Preemergence Herbicide Programs for Control of Protoporphyrinogen Oxidase-Resistant Amaranthus palmeri in Soybean
}

\author{
Michael M. Houston (D, L. Tom Barber, Jason K. Norsworthy, and Trent L. Roberts \\ Department of Crop Soil and Environmental Sciences, University of Arkansas, Fayetteville, AR 72704, USA \\ Correspondence should be addressed to Michael M. Houston; mmh027@uark.edu
}

Received 5 October 2020; Revised 5 February 2021; Accepted 9 February 2021; Published 18 February 2021

Academic Editor: Patrick J. Tranel

Copyright (c) 2021 Michael M. Houston et al. This is an open access article distributed under the Creative Commons Attribution License, which permits unrestricted use, distribution, and reproduction in any medium, provided the original work is properly cited.

\begin{abstract}
Protoporphyrinogen oxidase- (PPO-) resistant Amaranthus palmeri (S.) Wats. (Palmer amaranth) was confirmed in Arkansas in 2015. Field trials were conducted in Crawfordsville, Gregory, and Marion, Arkansas in 2016, and Crawfordsville and Marion in 2017, assessing PPO-resistant Palmer amaranth control options in Glycine max (L.) Merr. (soybean). Twelve trials consisted of 26 preemergence (PRE) treatments, evaluated for Palmer amaranth control and density reduction at 28 days after treatment (DAT). Treatments that consisted of PPO- or acetolactate synthase- (ALS-) inhibiting herbicides such as flumioxazin $\left(72 \mathrm{~g}\right.$ ai ha $\left.{ }^{-1}\right)$ or sulfentrazone + cloransulam $\left(195 \mathrm{~g} \mathrm{ha}^{-1}+25 \mathrm{~g} \mathrm{ha}^{-1}\right)$ controlled Palmer amaranth $<60 \%$. At 28 DAT, treatments including mixtures of a very-long-chain fatty acid (VLCFA) plus the photosystem II- (PSII-) inhibiting herbicide metribuzin provided increased control over single herbicide sites of action (SOA) or herbicides mixtures to which Palmer amaranth was resistant. Pyroxasulfone + metribuzin $\left(149 \mathrm{~g} \mathrm{ha}^{-1}+314 \mathrm{~g} \mathrm{ha}^{-1}\right)$ controlled Palmer amaranth $91 \%$ control across twelve trials at 28 DAT. Smetolachlor alone did not provide consistent, acceptable control of PPO-resistant Palmer amaranth (55-77\%); subsequent research has determined that these populations are resistant to $S$-metolachlor. A minimum of two effective herbicides should be included in soybean PRE programs for control of PPO-resistant Palmer amaranth.
\end{abstract}

\section{Introduction}

Over-reliance on a single herbicide site of action (SOA) perpetuates the evolution and spread of herbicide-resistant biotypes [1-3]. In Amaranthus palmeri (S.) Wats. (Palmer amaranth), the repeated use of acetolactate synthase-(ALS-) inhibiting herbicides and glyphosate was selected for Palmer amaranth with mechanisms of resistance to one or both of these SOA [4-6]. Subsequently, growers shifted to PRE followed by residual postemergence (POST) weed management programs $[7,8]$.

After the identification of GR-resistant Palmer amaranth, use of PPO-inhibiting herbicides increased, offering both residual and foliar control of GR-resistant Palmer amaranth $[9,10]$. PPO inhibitors offered both versatile and reliable control of Palmer amaranth [11, 12]. Fomesafen, a PPO-inhibiting herbicide in the diphenylether family, use increased from 2 to $16 \%$ of all US soybean acreage after confirmation of GR-resistant Palmer amaranth $[7,8]$, with the heaviest reliance on this herbicide in the Midsouth. Only two herbicides were used on more acreage in the US, sulfentrazone $(17 \%)$, which is another PPO-inhibiting herbicide, and glyphosate (85\%) [8].

Season-long Amaranthus control is usually greater with the use of PRE herbicides. Hoffner et al. [13] reported that $S$-metolachlor and fomesafen PRE followed by glufosinate POST controlled Palmer amaranth better than sequential applications of glufosinate. In a similar experiment, at-harvest Amaranthus rudis (Moq.) Sauer (waterhemp) control with one glufosinate application was improved 22\% when following flumioxazin PRE [14]. These findings lead to the conclusion that inclusion of PRE and residual POST herbicides increase season-long Amaranthus control, even when utilizing an effective, 
nonresidual POST herbicide. Modeled resistance risk in Palmer amaranth was found to be reduced when effective PRE herbicides were included with POST programs [15]. Reduced resistance risk, improved season-long control, and confirmed ALS- and GR-resistant Palmer amaranth made residual herbicides, especially PPO inhibitors, a necessary component of successful Palmer amaranth weed control programs in soybean $[6,15]$.

Palmer amaranth resistance to PPO inhibitors was first reported in 2015 [1, 16]. Previously, waterhemp had been the focus of PPO resistance research, with seven states having confirmed PPO-resistant biotypes [1]. Susceptible Palmer amaranth PPO amino acid sequences were identical to susceptible waterhemp before the $\Delta \mathrm{G} 210$ deletion occurred. Palmer amaranth, like waterhemp, remained absent of the nucleotide polymorphism seen in the Amaranthus acanthochiton at the replacement codon [17]. Riggins and Tranel [17] identified that the repeat motif in Palmer amaranth was identical to waterhemp for the PPX2 gene, which was confirmed as a mechanism for PPO resistance in waterhemp. Subsequently, this was shown to confer resistance to PPO inhibitors in Palmer amaranth as well. Known to hybridize, it is possible that the dioecious Amaranthus species crossed resulting in the transfer of the $\Delta$ G210 deletion to Palmer amaranth $[16,18,19]$. Two additional PPO resistance-conferring amino acid substitutions, Arg-128-Gly and Arg-128-Met, in Palmer amaranth were reported $[20,21]$. Each of these mutations has since been determined to confer cross-resistance to other PPO-inhibiting herbicides [22-24].

Field trials conducted in several locations showed that PRE applications of PPO-inhibiting herbicides remained an effective control option for PPO-resistant waterhemp $[24,25]$. In these field trials, PPO-resistant waterhemp was confirmed resistant not only to the diphenylether chemistry, but to all tested PPO-inhibiting herbicides [10,25]. Wuerffel et al. [10] and Tranel et al. [3] noted the potential dangers for PPO-resistant waterhemp if PRE use continued on this biotype. As shown in a study by Wuerffel et al. [10], adding an effective herbicide such as $S$-metolachlor can help delay resistance selection by decreasing the number of resistant plants that survive. Preemergence applications of PPOinhibiting herbicides provided some control of resistant waterhemp, but the addition of another effective SOA with residual activity often resulted in improved and more consistent control across environments [10, 24, 25].

As early as 1998, waterhemp control with sulfentrazone and flumioxazin was improved when co-applied with another effective residual herbicide such as metribuzin $[9,11]$. Evidence supporting the benefit of PPO inhibitors, even after the confirmation of PPO-resistant Amaranthus, could lead to continued utilization of this chemistry if they are applied along with other effective herbicides.

With widespread ALS- and PPO-resistant Palmer amaranth, control using PRE herbicide programs once deemed effective needed to be reevaluated $[4,5,16,23]$. The objective of this research was to evaluate the effectiveness of PREapplied herbicide programs for control of PPO-resistant Palmer amaranth.

\section{Materials and Methods}

Field experiments were conducted on commercial farms near Marion, AR, on a Dubbs silt loam (fine-silty, mixed, active, thermic Typic Hapludalfs) in 2016 and 2017; Gregory, $\mathrm{AR}$, on a Wiville sandy loam (fine-loamy, siliceous, active, thermic Utic Hapludalfs) in 2016; and Crawfordsville, AR, on both a Forestdale silty clay loam (fine, smectitic, thermic Typic Endoaqualfs) in 2016 and a Dundee silt loam (finesilty, mixed, active, thermic Typic Endoaqualfs) in 2016 and 2017. The soil near Marion had a pH of 5.8 with $1.6 \%$ organic matter and the soil for both fields near Crawfordsville had a $\mathrm{pH}$ of 5.28 and 5.34 with an organic matter content of 1.8 and $1.95 \%$. Plots consisted of 4 single rows, spaced $97 \mathrm{~cm}$ apart at a density of 370,500 seeds $\mathrm{ha}^{-1}$ in Marion, rows, spaced $19 \mathrm{~cm}$ apart, at 449,540 seeds $\mathrm{ha}^{-1}$ in Gregory, and rows, spaced $97 \mathrm{~cm}$ apart, at 345,800 seeds ha ${ }^{-1}$ in Crawfordsville (Table 1). Trials were set up with $9.1 \mathrm{~m}$ long by $3.9 \mathrm{~m}$ wide plots in Marion, $6.1 \mathrm{~m}$ long by $2.3 \mathrm{~m}$ wide plots in Gregory, and $7.6 \mathrm{~m}$ long by $3.9 \mathrm{~m}$ wide plots in Crawfordsville. Group IV soybean varieties were used for this experiment and are listed along with planting dates in Table 1 . Herbicide applications were made at $140 \mathrm{~L} \mathrm{ha}^{-1}$ with a four-nozzle boom attached to a $\mathrm{CO}_{2}$-pressurized backpack sprayer in Crawfordsville and $112 \mathrm{~L} \mathrm{ha}^{-1}$ using a Bowman Mudmaster ${ }^{\mathrm{TM}}$ multiboom system in Marion and Gregory. All herbicides were applied with 110015 TeeJet ${ }^{\circledast}$ air induction extended range nozzles at a speed of $4.8 \mathrm{kph}$. All locations were absent of irrigation, requiring precipitation for PRE treatment activation. Listed in Table 2, precipitation gathered from on-site weather stations for each site-year shows at least $1.72 \mathrm{~cm}$ of rainfall within the first 14 days after treatment (DAT).

Twenty-five PRE programs were evaluated in soybean for Palmer amaranth control, not including the nontreated control. PRE programs consisted of single active ingredients and herbicide mixtures with more than one SOA. Preemergence treatments focused on four distinct SOAs: ALS-, PPO-, very-long-chain fatty acid- (VLCFA-), and PSIIinhibiting herbicides. Table 3 is a comprehensive list of treatment composition, herbicide group, and rate of each herbicide. Visible estimates of Palmer amaranth control and Palmer amaranth density in each plot were recorded 28 DAT, targeting evaluations before a typical POST application timing. Ratings were taken on a 0 to $100 \%$ scale, with $0 \%$ representing no control and 100\% indicating complete weed mortality [26]. To determine Palmer amaranth density, two separate counts per $0.5 \mathrm{~m}^{2}$ were counted in the center two rows of the plots. Palmer amaranth density on a $\mathrm{m}^{2}$ basis was then converted to a percentage relative to counts in the nontreated control. Palmer amaranth densities were not recorded at the Gregory location, hence the exclusion of this site in Table 3.

Data were analyzed using JMP Genomics 8 (SAS Institute Inc., SAS Campus Drive, Cary, North Carolina 27513). This experiment was set up as a randomized complete block design with four replications, utilizing data from 10 trials in 2016, and 2 in 2017. Experiments were analyzed across location and separately by year using a fit model and 
TABLE 1: Locations, soybean varieties, planting dates, row spacings, and seeding rates for 12 trials conducted in Arkansas, USA, in 2016 and 2017.

\begin{tabular}{|c|c|c|c|c|c|}
\hline Location & Variety & Technology & Planting date & Row spacing $(\mathrm{cm})$ & Seeding rate $\left(1,000\right.$ seed $\left.\mathrm{ha}^{-1}\right)$ \\
\hline \multirow{5}{*}{ Crawfordsville } & AG $47 \times 6$ & Roundup ready & May 11, 2016 & 97 & 346 \\
\hline & AG $47 \times 6$ & Roundup ready 2 xtend & May 11, 2016 & 97 & 346 \\
\hline & HBK $4950 \mathrm{LL}$ & LibertyLink & May 11, 2016 & 97 & 346 \\
\hline & 43R15Y9 & Enlist & June 10, 2016 & 97 & 346 \\
\hline & P49T09 BR & LibertyLink & May 22, 2017 & 97 & 346 \\
\hline \multirow{3}{*}{ Gregory } & AG 4633 & Roundup ready & May 5, 2016 & 19 & 450 \\
\hline & DG 4957 LL & LibertyLink & May 5, 2016 & 19 & 450 \\
\hline & 43R15Y9 & Enlist & May 5, 2016 & 19 & 450 \\
\hline \multirow{4}{*}{ Marion } & AG 4632 & Roundup ready & May 12,2016 & 97 & 370 \\
\hline & AG $47 \times 6$ & Roundup ready 2 xtend & May 12, 2016 & 97 & 370 \\
\hline & P49T31 LL & LibertyLink & May 12, 2016 & 97 & 370 \\
\hline & HBK 4953 LL & LibertyLink & May 10, 2017 & 97 & 370 \\
\hline
\end{tabular}

Abbreviations: AG, Asgrow, Bayer CropScience, Research Triangle Park, NC 27709; DG, Delta Grow, Delta Grow Seed, England, AR 72046; HBK, Hornbeck, Hornbeck Seed Company, De Witt, AR 72042; P, Pioneer, DowDupont Midland, MI 48674; 43R15Y9, Enlist soybean variety designation, Corteva, Midland, MI 48674.

TABle 2: Accumulated rainfall following PRE herbicide application from 12 trials conducted near Crawfordsville, Gregory, and Marion, Arkansas, in 2016 and $2017^{\mathrm{a}}$.

\begin{tabular}{|c|c|c|c|c|c|c|}
\hline \multirow[b]{3}{*}{ DAT } & \multicolumn{6}{|c|}{ Rainfall $^{\mathrm{b}}$} \\
\hline & \multicolumn{4}{|c|}{2016} & \multicolumn{2}{|c|}{2017} \\
\hline & \multicolumn{2}{|c|}{ Crawfordsville $^{c}$} & \multirow[t]{2}{*}{ Gregory } & \multirow{2}{*}{$\frac{\text { Marion }}{\mathrm{m}}$} & \multirow[t]{2}{*}{ Crawfordsville } & \multirow[t]{2}{*}{ Marion } \\
\hline & & & & & & \\
\hline 7 & 0.28 & 3.91 & 1.47 & 0.58 & 3.15 & 1.57 \\
\hline 14 & 3.63 & 0 & 0.25 & 3.53 & 1.57 & 1.98 \\
\hline 21 & 4.90 & 3.68 & 3.96 & 1.80 & 0 & 3.45 \\
\hline 28 & 0.28 & 2.59 & 4.75 & 0.18 & 3.15 & 1.19 \\
\hline 35 & 3.91 & 2.06 & 0.25 & 3.91 & 6.80 & 0 \\
\hline 42 & 0 & 0.18 & 0 & 0 & 0.23 & 3.18 \\
\hline
\end{tabular}

${ }^{a}$ Abbreviation: DAT, days after treatment. ${ }^{\text {b }}$ Values represent cumulative precipitation from previous timing. ${ }^{c}$ Two columns are presented for Crawfordsville in 2016 as three experiments were established on May $12^{\text {th }}, 2016$, represented by the first column, and one was established on June $10^{\text {th }}, 2016$, represented by the second column.

beta distribution. Replication was considered a random effect in each individual model, and treatment was designed as a fixed effect in each model. Box and whisker plots were also included to provide treatment variation, which demonstrate both outliers and the range of control of individual treatments (Figures 1 and 2). Means and separation are included, which were derived from a Tukey's HSD of visible control ratings. As explained in each figure, a sample size of 32 points for each treatment was included in 2016, and 8 in 2017. Data from the nontreated were excluded and not used in analyses. Where appropriate, data were separated using Tukey's HSD $(P=0.05)$.

\section{Results and Discussion}

There was a minimum of $1.72 \mathrm{~cm}$ of precipitation within the first $14 \mathrm{DAT}$ at all environments (Table 2). Experiments at each location were conducted using common producer methods, with a considerable difference in seeding rate and row-spacing (Table 1). Gregory, Marion, and Crawfordsville Palmer amaranth populations were all previously confirmed to be PPO-, ALS-, and GR-resistant $[1,16,22,23]$. The mechanisms of PPO resistance were confirmed as follows for the three locations: Crawfordsville $(\Delta \mathrm{G} 210)$, Gregory ( $\triangle \mathrm{G} 210$; Arg-128), and Marion (Arg-128).

3.1. Palmer Amaranth Response in 2016. The nontreated plots at Marion and Crawfordsville in 2016 averaged 221 Palmer amaranth plants $\mathrm{m}^{-2}$ at 28 DAT (data not shown). For all herbicide treatments at $28 \mathrm{DAT}$, Palmer amaranth density reduction ranged from 30 to $95 \%$ (Table 3). Sulfentrazone + cloransulam $\left(196+25 \mathrm{~g} \mathrm{ha}^{-1}\right)$ reduced Palmer amaranth density the least, and saflufenacil + dimethenamid-p + pyroxasulfone + metribuzin $(25+219+149+314$ $\mathrm{g} \mathrm{ha}^{-1}$ ) reduced Palmer amaranth density the most. The low Palmer amaranth reduction with PPO-inhibiting herbicides was apparent. For example, flumioxazin $\left(72 \mathrm{~g} \mathrm{ha}^{-1}\right)$ alone reduced Palmer amaranth density $35 \%$ at 28 DAT. Furthermore, because of confirmed ALS resistance at these sites, PRE treatments that consisted only of a PPO or ALS inhibitor reduced Palmer amaranth an average of 55\% (Table 3). The only herbicide tank-mix of an ALS- plus PPOinhibiting herbicide that reduced Palmer amaranth density 
TABLE 3: Palmer amaranth density reduction following PRE herbicide application in soybean from 12 trials conducted near Crawfordsville and Marion, Arkansas, in 2016 and $2017^{\mathrm{a}, \mathrm{b}, \mathrm{c}}$.

\begin{tabular}{|c|c|c|c|c|c|c|}
\hline \multirow{3}{*}{ Herbicide } & \multirow[t]{3}{*}{ Rate } & \multirow[t]{2}{*}{ WSSA group } & \multicolumn{4}{|c|}{ Density $^{\mathrm{d}}$} \\
\hline & & & \multicolumn{2}{|c|}{2016} & \multicolumn{2}{|c|}{2017} \\
\hline & & $\mathrm{g}$ ai ha ${ }^{-1}$ & \multicolumn{4}{|c|}{$\%$} \\
\hline \multirow{4}{*}{ Saflufenacil + dimethenamid-p + pyroxasulfone + metribuzin } & 25 & 14 & \multirow{4}{*}{95} & \multirow{4}{*}{ a } & \multirow{4}{*}{98} & \multirow{4}{*}{$\mathrm{a}$} \\
\hline & 219 & 15 & & & & \\
\hline & 149 & 15 & & & & \\
\hline & 314 & 5 & & & & \\
\hline \multirow{2}{*}{ Flumioxazin + pyroxasulfone } & 88 & 14 & \multirow{2}{*}{93} & \multirow{2}{*}{ a } & & $a$ \\
\hline & 111 & 15 & & & 98 & $\mathrm{a}$ \\
\hline$S$-metolachlor + metribuzin & 1,105 & 15 & 92 & $a$ & 85 & $\mathrm{ab}$ \\
\hline s-metoracnior + metriouzin & 242 & 5 & 92 & $\mathrm{a}$ & 85 & $\mathrm{ab}$ \\
\hline & 70 & 14 & & & & \\
\hline & 250 & 5 & & & & \\
\hline Flumioxazin + metribuzin + chlorimuron-ethyl + pyroxasulfone & 22 & 2 & 91 & a & 97 & $\mathrm{a}$ \\
\hline & 90 & 15 & & & & \\
\hline Pyroxasulfone + metribuzin & 149 & 15 & & & & a \\
\hline Pyroxasulfone + metribuzın & 314 & 5 & 90 & $\mathrm{a}$ & 98 & $\mathrm{a}$ \\
\hline & 343 & 5 & & & & \\
\hline Metribuzin + chlorimuron-ethyl $+S$-metolachlor & 17 & 2 & 90 & $\mathrm{a}$ & 96 & $\mathrm{a}$ \\
\hline & 1,105 & 15 & & & & \\
\hline & 269 & 5 & & & & \\
\hline Metribuzin + chlorimuron-ethyl $+S$-metolachlor & 45 & 2 & 88 & $\mathrm{ab}$ & 67 & $\mathrm{~cd}$ \\
\hline & 1,070 & 15 & & & & \\
\hline & 78 & 14 & & & & \\
\hline Flumioxazin + pyroxasulfone + chlorimuron-ethyl & 98 & 15 & 86 & $\mathrm{ab}$ & 98 & a \\
\hline & 21 & 2 & & & & \\
\hline S.metolachlor t metribuzin & 1,389 & 15 & 86 & ah & 94 & ah \\
\hline S-metolachlor + metribuzin & 420 & 5 & 86 & $\mathrm{ab}$ & 94 & $\mathrm{ab}$ \\
\hline & 269 & 5 & & & & \\
\hline Metribuzin + chlorimuron-ethyl + pyroxasulfone & 45 & 2 & 85 & $\mathrm{ab}$ & 92 & $\mathrm{ab}$ \\
\hline & 90 & 15 & & & & \\
\hline Flumioxazin + cloransulam & 106 & 14 & 84 & $3-c$ & 88 & ah \\
\hline Flumioxazin + cloransulam & 35 & 2 & 84 & $\mathrm{a}-\mathrm{c}$ & 88 & $\mathrm{aD}$ \\
\hline & 70 & 14 & & & & \\
\hline Flumioxazin + metribuzin + chlorimuron-ethyl & 250 & 5 & 80 & $a-c$ & 92 & $\mathrm{ab}$ \\
\hline & 22 & 2 & & & & \\
\hline & 134 & 14 & & & & \\
\hline Sulfentrazone $+S$-metolachlor & 1,210 & 15 & 78 & $\mathrm{a}-\mathrm{c}$ & 86 & $a b$ \\
\hline Flumioxazin + cloransulam & 71 & 14 & 74 & $a-c$ & 79 & $a-c$ \\
\hline & 24 & 2 & & & & $\mathrm{a}-\mathrm{C}$ \\
\hline & 76 & 14 & & & & \\
\hline Flumioxarin tshlorimuron_ethyl t thifenculfuron + nuroyaculfone & 13 & 2 & 73 & & & $\mathrm{ab}$ \\
\hline Flumioxazin + chlorimuron-ethyl + thifensulfuron + pyroxasulfone & 4 & 2 & 73 & $\mathrm{a}-\mathrm{c}$ & 93 & $a b$ \\
\hline & 90 & 15 & & & & \\
\hline Metribuzin & 420 & 5 & 73 & $a-c$ & 74 & $a-c$ \\
\hline & 72 & 14 & & & & \\
\hline Flumioxazin + chlorimuron-ethyl + thifensulfuron + pyroxasulfone & 23 & 2 & 67 & & & $a b$ \\
\hline & 7 & 2 & 67 & $\mathrm{a}-\mathrm{c}$ & 94 & \\
\hline & 90 & 15 & & & & \\
\hline & 76 & 14 & & & & \\
\hline Flumioxazin + chlorimuron-ethyl + thifensulfuron & 13 & 2 & 61 & $a-c$ & 73 & $a-c$ \\
\hline & 4 & 2 & & & & \\
\hline Flumioxazin + chlorimuron-ethyl & 63 & 14 & 56 & 急 & 77 & $a-c$ \\
\hline Flumıoxazın + chlorımuron-ethyl & 22 & 2 & 56 & $\mathrm{a}-\mathrm{c}$ & $/ / 7$ & $\mathrm{a}-\mathrm{c}$ \\
\hline$S$-metolachlor & 1,064 & 15 & 55 & $a-c$ & 79 & $a-c$ \\
\hline & 72 & 14 & & & & \\
\hline Flumioxazin + chlorimuron-ethyl + thifensulfuron & 23 & 2 & 53 & $a-c$ & 87 & $\mathrm{ab}$ \\
\hline & 7 & 2 & & & & \\
\hline
\end{tabular}


TABLE 3: Continued.

\begin{tabular}{|c|c|c|c|c|c|c|}
\hline \multirow{3}{*}{ Herbicide } & \multirow[t]{2}{*}{ Rate } & \multirow[t]{2}{*}{ WSSA group } & \multicolumn{4}{|c|}{ Density $^{\mathrm{d}}$} \\
\hline & & & \multicolumn{2}{|c|}{2016} & \multicolumn{2}{|c|}{2017} \\
\hline & \multicolumn{2}{|c|}{$\mathrm{g}$ ai ha ${ }^{-1}$} & \multicolumn{4}{|c|}{$\%$} \\
\hline \multirow{2}{*}{ Sulfentrazone + metribuzin } & 188 & 14 & \multirow{2}{*}{51} & \multirow{2}{*}{$a-c$} & \multirow{2}{*}{77} & \multirow{2}{*}{$a-c$} \\
\hline & 282 & 5 & & & & \\
\hline \multirow{2}{*}{ Sulfentrazone + cloransulam } & 130 & 14 & \multirow{2}{*}{47} & \multirow{2}{*}{$a-c$} & \multirow{2}{*}{31} & \multirow{2}{*}{$\mathrm{d}$} \\
\hline & 17 & 2 & & & & \\
\hline Flumioxazin & 72 & 14 & 35 & bc & 77 & $a-c$ \\
\hline Sulfentrazone + cloransulam & 196 & 14 & 30 & $\mathrm{c}$ & 54 & $\mathrm{~cd}$ \\
\hline Herbicide ( $P$-value) & 25 & 2 & \multicolumn{2}{|c|}{$<0.0001$} & \multicolumn{2}{|c|}{$<0.0001$} \\
\hline
\end{tabular}

${ }^{a}$ Abbreviations: DAT, days after treatment; WSSA, Weed Science Society of America. ${ }^{b}$ Means within a column followed by the same lowercase letter are not different based on Tukey's HSD $(P=0.05)$. ${ }^{c}$ Average Palmer amaranth density for the nontreated control was 217 per $\mathrm{m}^{2}$ in 2016 and 37 per $\mathrm{m}^{2}$ in 2017.

${ }^{\mathrm{d}}$ Gregory not included as density data are not available.

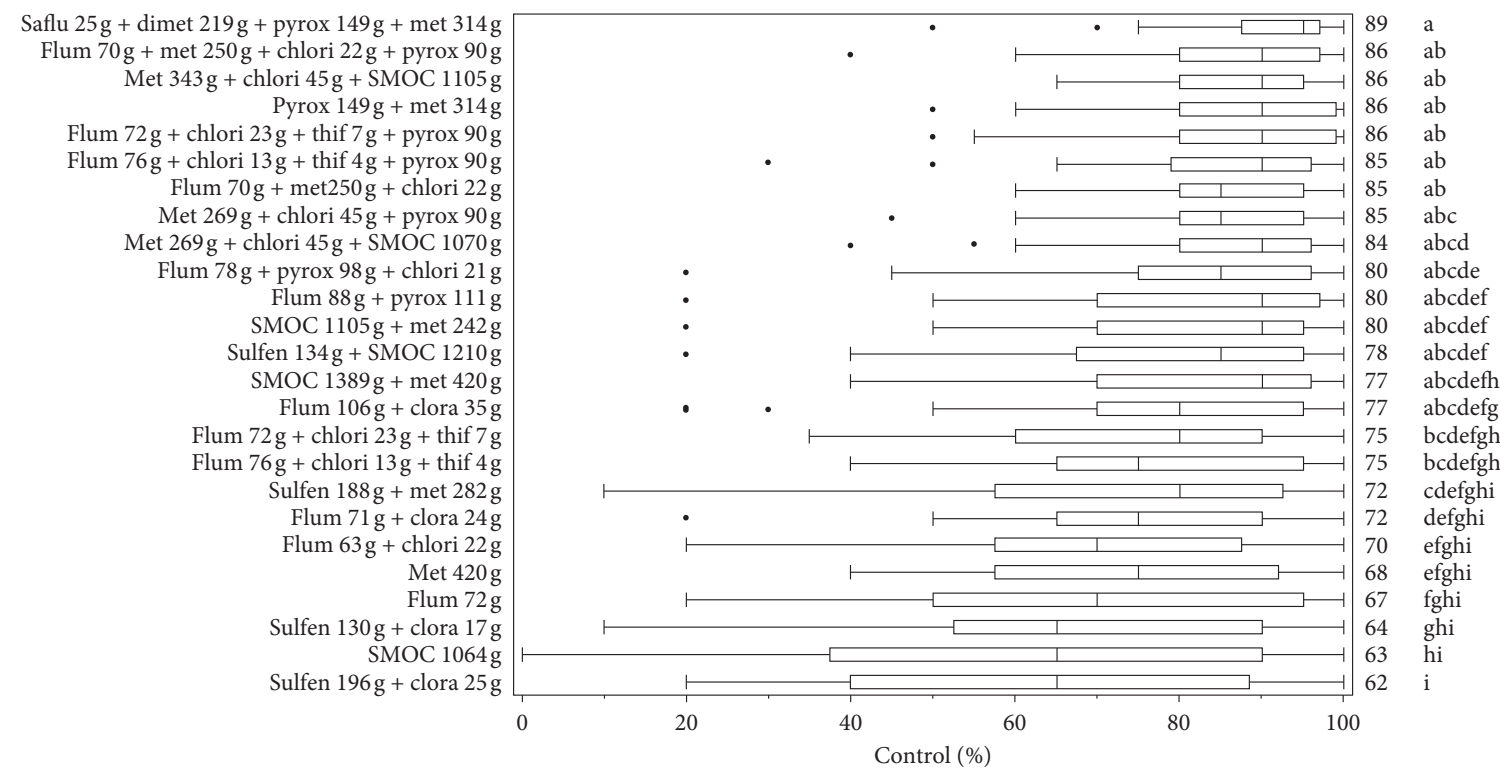

FIgURE 1: Box and whisker plots for Palmer amaranth control at 28 days after treatment (DAT) over locations in 2016. Statistical means and separation are shown with the corresponding treatment in descending order, derived from a Tukey's HSD. Each treatment listed included a sample size of 32 data points. Use rates are provided to the right of each herbicide in $\mathrm{g}$ ai ha ${ }^{-1}$. Abbreviations: chlori, chlorimuron-ethyl; clora, cloransulam; dimet, dimethenamid-p; flum, flumioxazin; met, metribuzin; pyrox, pyroxasulfone; saflu, saflufenacil; SMOC, S-metolachlor; sulfen, sulfentrazone; thif, thifensulfuron.

$>80 \%$ was flumioxazin + cloransulam $\left(106+35 \mathrm{gha}^{-1}\right)$ at $84 \%$. Although reliance on these SOAs alone results in poor Palmer amaranth control, the combination of PPO and ALS inhibitors with other effective herbicides is still a viable option. This is demonstrated by treatments such as flumioxazin + pyroxasulfone $\left(88+111 \mathrm{~g} \mathrm{ha}^{-1}\right)$, which reduced Palmer amaranth density $93 \%$ at 28 DAT.

Preemergence treatments that include both Group 5 and 15 herbicides reduced Palmer amaranth density an average of $90 \%$ (Table 3). Tank-mixtures containing Group 5 and 15 herbicides control Palmer amaranth at an average of $87 \%$ across all mixtures over both years, which was achieved when mixing these two herbicide groups as shown in
Figure 1. Comparison of treatment means for the box and whisker plots can be derived from an ANOVA mentioned previously $(P<0.0001)$. Herbicide treatments that consisted of only one herbicide, regardless of SOA, controlled Palmer amaranth $<68 \%$. This result was not surprising because in previous greenhouse research on some of these populations, the single SOA herbicide treatments had low efficacy on these multiple-herbicide-resistant Palmer amaranth populations [22]. Surprisingly, $S$-metolachlor $\left(1064 \mathrm{~g} \mathrm{ha}^{-1}\right)$, controlled Palmer amaranth an average of $63 \%$, had an extremely wide range of control at 28 DAT (Figure 1). Poor control with $S$-metolachlor is also reflected by the $55 \%$ density reduction (Table 3 ). Just recently, $S$-metolachlor- 


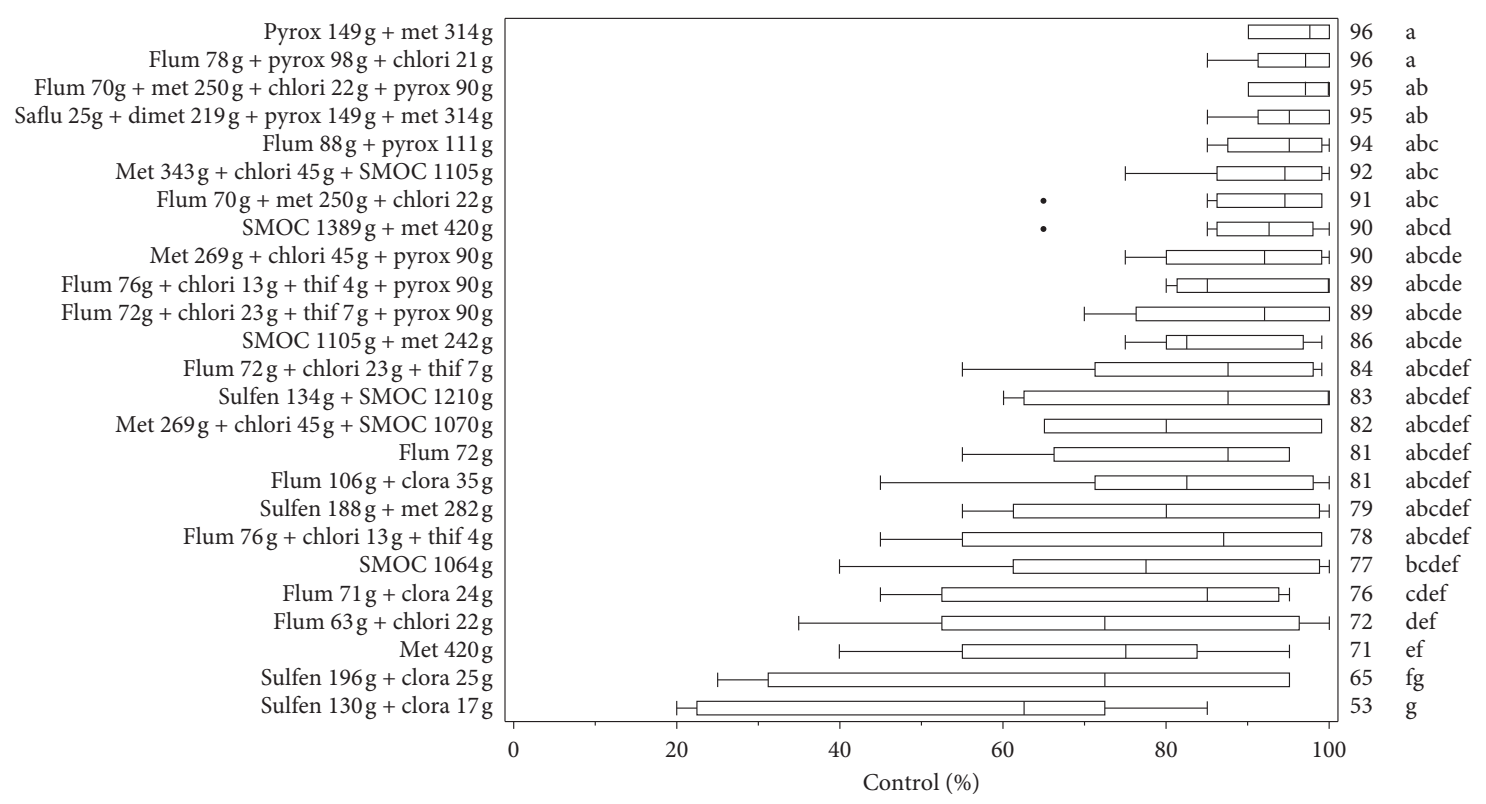

Figure 2: Box and whisker plots for Palmer amaranth control at 28 days after treatment (DAT) over locations in 2017. Statistical means and separation are shown with the corresponding treatment in descending order, derived from a Tukey's HSD. Each treatment listed included a sample size of 8 data points. Use rates are provided to the right of each herbicides in $\mathrm{g}$ ai ha ${ }^{-1}$. ${ }^{\mathrm{a}} \mathrm{Abbreviations:} \mathrm{chlori,} \mathrm{chlorimuron-ethyl;}$ clora, cloransulam; dimet, dimethenamid-p; flum, flumioxazin; met, metribuzin; pyrox, pyroxasulfone; saflu, saflufenacil; SMOC, S-metolachlor; sulfen, sulfentrazone; thif, thifensulfuron.

resistant Palmer amaranth have been confirmed at the Marion and Crawfordsville sites [1, 27], but no resistance testing or confirmation has occurred for the Gregory population.

3.2. Palmer Amaranth Response in 2017. The two trials conducted in 2017 focused exclusively on the Marion and Crawfordsville sites. The nontreated plots across Marion and Crawfordsville in 2017 averaged 75 Palmer amaranth per $\mathrm{m}^{-2}$ at 28 DAT (data not shown). The likely reason for the lower density in 2017 is that Palmer amaranth seed production was not allowed at these sites in 2016. Improved herbicide efficacy in the second year can be attributed, in part, to lower Palmer amaranth density; trends in herbicide efficacy were consistent between years. Palmer amaranth density reduction ranged from 31 to $98 \%$ in 2017 (Table 3). In 2017, two PRE treatments with ALS- and PPO-inhibiting herbicides, flumioxazin + cloransulam $\left(106+35 \mathrm{~g} \mathrm{ha}^{-1}\right)$ and flumioxazin + chlorimuron-ethyl + thifensulfuron $\left(72+23+7 \mathrm{~g} \mathrm{ha}^{-1}\right)$, controlled ALS- and PPO-resistant Palmer amaranth 88 and 87\%, respectively. In 2017, density reduction at 28 DAT shows that reliance on PPO or ALS inhibitors alone would often result in poor control of these Palmer amaranth populations, especially without the presence of a Group 5 or 15 herbicide. Box and whisker plots, with corresponding means and separation, for 28 DAT in 2017 show less variability in the majority of treatments versus 2016 (Figure 2). The more consistent response of herbicides among replications and the two locations in 2017 is in part why years were analyzed separately for visible estimates of control, as the $P$ value for the year effect was 0.0016 when included in the ANOVA model. There was no significant effect for site during this analysis for 2016 or 2017.
At 28 DAT, metribuzin controlled PPO-resistant Palmer amaranth $71 \%$. Visible estimates of Palmer amaranth control for $S$-metolachlor, while higher than in 2016, averaged only $77 \%$, with a relatively high amount of variation across plots and locations (Figure 2). This finding leads to the hypothesis that control of these Palmer amaranth populations with $S$ metolachlor alone could be extremely variable depending on year and location, which may contribute to the evolution of $S$-metolachlor-resistant Palmer amaranth. However, including this herbicide as part of an effective PRE program still has benefit in that it provides some Palmer amaranth control as well as other weeds such as barnyard grass (Echinochloa crus-galli L. Beauv.), the most common grass weed of soybean in this region.

3.3. Practical Implications. Reliance on PPO- and ALSinhibiting herbicides for PRE control of glyphosate-, ALS-, and PPO-resistant Palmer amaranth provided less than acceptable control at $28 \mathrm{DAT}$ and will put added pressure on POST herbicides for acceptable weed control. It was evident that PRE programs including metribuzin and a Group 15 herbicide can successfully control PPO-resistant Palmer amaranth for the first four weeks after soybean planting. However, reliance on $S$-metolachlor or metribuzin alone failed to provide acceptable control, hence the need for two or more PRE herbicides. For both 2016 and 2017, treatments containing pyroxasulfone never provided $<80 \%$ control and averaged $89 \%$ control across all site-years. This indicates pyroxasulfone remains one of the few proven, effective herbicides for control of PPO-resistant Palmer amaranth. $S$ metolachlor-resistant Palmer amaranth, now confirmed in Crawfordsville and Marion, Arkansas, has further limited 
potential weed control options in soybean. Although $S$ metolachlor can be used in combination with other effective herbicides, it should be noted that reduced efficacy is likely with the confirmation of $S$-metolachlor-resistant Palmer amaranth in 2019 [27]. Also, it should be noted that there is a slight reduction in sensitivity of the Marion and Crawfordsville accessions to pyroxasulfone [27] and continued reliance on this Group 15 herbicide could increase the selection intensity for Group 15 resistance in these fields. While flumioxazin was not deemed effective alone (67 to $81 \%)$, the data suggested it does have value in a tank-mix PRE application for control of PPO-resistant Palmer amaranth. The coapplication of two or more effective SOAs is recommended for control of Palmer amaranth.

\section{Data Availability}

The underlying data for this experiment set are held on a device accessible by the corresponding author.

\section{Disclosure}

This experiment is part of thesis work by the corresponding author and is available at https://scholarworks.uark.edu/etd/ $3395 /$.

\section{Conflicts of Interest}

The authors declare no conflicts of interest.

\section{Acknowledgments}

This research was graciously funded by the Arkansas Soybean Research and Promotion Board.

\section{References}

[1] I. M. Heap, "International survey of herbicide resistant weeds,” 2019, http://www.weedscience.org/in.asp.

[2] J. K. Norsworthy, S. M. Ward, D. R. Shaw et al., "Reducing the risks of herbicide resistance: best management practices and recommendations," Weed Science, vol. 60, no. 1, pp. 31-62, 2012.

[3] P. J. Tranel, C. W. Riggins, M. S. Bell, and A. G. Hager, "Herbicide resistances in Amaranthus tuberculatus: a call for new options," Journal of Agricultural and Food Chemistry, vol. 59, no. 11, pp. 5808-5812, 2011.

[4] J. A. Bond, L. R. Oliver, and D. O. Stephenson, "Response of Palmer amaranth (Amaranthus palmeri) accessions to glyphosate, fomesafen, and pyrithiobac," Weed Technology, vol. 20 , no. 4 , pp. 885-892, 2006.

[5] N. R. Burgos, Y.-I. Kuk, and R. E. Talbert, "Amaranthus palmeri resistance and differential tolerance of Amaranthus palmeri and Amaranthus hybridus to ALS-inhibitor herbicides," Pest Management Science, vol. 57, no. 5, pp. 449-457, 2001.

[6] J. K. Norsworthy, G. M. Griffith, R. C. Scott, K. L. Smith, and L. R. Oliver, "Confirmation and control of glyphosate-resistant Palmer amaranth (Amaranthus palmeri) in Arkansas," Weed Technology, vol. 22, no. 1, pp. 108-113, 2008.

[7] [USDA-NASS] United States Department of Agriculture National Agriculture Statistics Service, "2005 agriculture chemical use survey," 2005, http://usda.mannlib.cornell.edu/ usda/nass/AgChemUsDistRate/2000s/2005/

AgChemUsDistRate-12-23-2005.txt.

[8] [USDA-NASS] United States Department of Agriculture National Agriculture Statistics Service, "2015 agriculture chemical use survey," 2015, https://www.nass.usda.gov/ Surveys/Guide_to_NASS_Surveys/Chemical_Use/2015_ Cotton_Oats_Soybeans_Wheat_Highlights/

ChemUseHighlights_Soybeans_2015.pdf.

[9] R. F. Krausz, G. Kapusta, and J. L. Matthews, "Sulfentrazone for weed control in soybean (Glycine max)," Weed Technology, vol. 12, no. 4, pp. 684-689, 1998.

[10] R. J. Wuerffel, J. M. Young, P. J. Tranel, and B. G. Young, "Soil-residual protoporphyrinogen oxidase-inhibiting herbicides influence the frequency of associated resistance in waterhemp (Amaranthus tuberculatus)," Weed Science, vol. 63, no. 2, pp. 529-538, 2015.

[11] J. W. Niekamp, W. G. Johnson, and R. J. Smeda, "Broadleaf weed control with sulfentrazone and flumioxazin in no-tillage soybean (Glycine max)," Weed Technology, vol. 13, pp. 322-238, 1999.

[12] J. R. Whitaker, A. C. York, D. L. Jordan, A. S. Culpepper, and L. M. Sosnoskie, "Residual herbicides for Palmer amaranth control," Journal of Cotton Science, vol. 15, pp. 89-99, 2011.

[13] A. E. Hoffner, D. L. Jordan, A. Chandi, A. C. York, E. J. Dunphy, and W. J. Everman, "Management of Palmer amaranth (Amaranthus palmeri) in glufosinate-resistant soybean (Glycine max) with sequential applications of herbicides," ISRN Agronomy, vol. 2012, Article ID 131650, 2012.

[14] J. S. Aulakh and A. J. Jhala, "Comparison of glufosinate-based herbicide programs for broad-spectrum weed control in glufosinate-resistant soybean," Weed Technology, vol. 29, no. 3, pp. 419-430, 2015.

[15] P. Neve, J. K. Norsworthy, K. L. Smith, and I. A. Zelaya, "Modeling glyphosate resistance management strategies for Palmer amaranth (Amaranthus palmeri) in cotton," Weed Technology, vol. 25, no. 3, pp. 335-343, 2011.

[16] R. A. Salas, N. R. Burgos, P. J. Tranel et al., "Resistance to PPO -inhibiting herbicide in Palmer amaranth from Arkansas," Pest Management Science, vol. 72, no. 5, pp. 864-869, 2016.

[17] C. W. Riggins and P. J. Tranel, "Will theAmaranthus tuberculatusResistance mechanism to PPO-inhibiting herbicides evolve in OtherAmaranthusSpecies?" International Journal of Agronomy, vol. 2012, Article ID 305764, 7 pages, 2012.

[18] J. D. Sauer, "The grain amaranths: a survey of their history and classification," Annals of the Missouri Botanical Garden, vol. 37, no. 4, pp. 561-632, 1950.

[19] L. E. Steckel, "The dioecious Amaranthus spp.: here to stay," Weed Technology, vol. 21, no. 2, pp. 567-570, 2007.

[20] D. A. Giacomini, A. M. Umphres, H. Nie et al., "Two new PPX2 mutations associated with resistance to PPO-inhibiting herbicides in Amaranthus palmeri," Pest Management Science, vol. 73, no. 8, pp. 1559-1563, 2017.

[21] R. A. Salas, N. R. Burgos, G. Rangani et al., "Frequency of Gly210 deletion mutation among protoporphyrinogen oxidase inhibitor-resistant Palmer amaranth (Amaranthus palmeri) populations," Weed Science, vol. 65, pp. 718-731, 2017.

[22] L. M. Schwartz-Lazaro, J. K. Norsworthy, R. C. Scott, and L. T. Barber, "Resistance of two Arkansas Palmer amaranth populations to multiple herbicide sites of action," Crop Protection, vol. 96, pp. 158-163, 2017.

[23] V. K. Varanasi, C. Brabham, J. K. Norsworthy et al., "A statewide survey of PPO-inhibitor resistance and the 
prevalent target-site mechanisms in Palmer amaranth (Amaranthus palmeri) accessions from Arkansas," Weed Science, vol. 66, no. 2, pp. 149-158, 2018.

[24] R. J. Wuerffel, J. M. Young, J. L. Matthews, and B. G. Young, "Characterization of PPO-Inhibitor-Resistant waterhemp (Amaranthus tuberculatus) response to soil-applied PPOinhibiting herbicides," Weed Science, vol. 63, no. 2, pp. 511-521, 2015.

[25] J. S. Falk, D. E. Shoup, K. Al-Khatib, and D. E. Peterson, "Protox-resistant common waterhemp (Amaranthus rudis) response to herbicides applied at different growth stages," Weed Science, vol. 54, no. 4, pp. 793-799, 2006.

[26] R. E. Frans and R. E. Talbert, "Design of field experiments and the measurement and analysis of plant responses," in Research Methods in Weed Science, B. Truelove, Ed., Southern Weed Science Society, 2nd edition, 1977.

[27] C. Brabham, J. K. Norsworthy, M. M. Houston, V. K. Varanasi, and T. Barber, "Confirmation ofS-metolachlor resistance in Palmer amaranth (Amaranthus palmeri)," Weed Technology, vol. 33, no. 5, pp. 720-726, 2019. 